\title{
Molecular Signatures in the Prevention of Radiation Damage by the Synergistic Effect of N-Acetyl Cysteine and Qingre Liyan Decoction, a Traditional Chinese Medicine, Using a 3-Dimensional Cell Culture Model of Oral Mucositis
}

\author{
Maria P. Lambros, ${ }^{1}$ Lavanya Kondapalli, ${ }^{1}$ Cyrus Parsa, ${ }^{2}$ Hari Chandana Mulamalla, ${ }^{1}$ \\ Robert Orlando, ${ }^{2}$ Doreen Pon, ${ }^{1}$ Ying Huang, ${ }^{1}$ and Moses S. S. Chow ${ }^{1,3}$ \\ ${ }^{1}$ College of Pharmacy, Western University of Health Sciences, Pomona, CA 91766, USA \\ ${ }^{2}$ College of Osteopathic Medicine, Western University of Health Sciences, Pomona, CA 91766, USA \\ ${ }^{3}$ Center for Advancement of Drug Research and Evaluation, Western University of Health Sciences, Pomona, CA 91766, USA \\ Correspondence should be addressed to Maria P. Lambros; mlambros@westernu.edu
}

Received 10 October 2014; Accepted 24 December 2014

Academic Editor: Kwok N. Leung

Copyright (C) 2015 Maria P. Lambros et al. This is an open access article distributed under the Creative Commons Attribution License, which permits unrestricted use, distribution, and reproduction in any medium, provided the original work is properly cited.

Qingre Liyan decoction (QYD), a Traditional Chinese medicine, and N-acetyl cysteine (NAC) have been used to prevent radiation induced mucositis. This work evaluates the protective mechanisms of QYD, NAC, and their combination (NAC-QYD) at the cellular and transcriptional level. A validated organotypic model of oral mucosal consisting of a three-dimensional (3D) cell tissue-culture of primary human keratinocytes exposed to X-ray irradiation was used. Six hours after the irradiation, the tissues were evaluated by hematoxylin and eosin (H and E) and a TUNEL assay to assess histopathology and apoptosis, respectively. Total RNA was extracted and used for microarray gene expression profiling. The tissue-cultures treated with NAC-QYD preserved their integrity and showed no apoptosis. Microarray results revealed that the NAC-QYD caused the upregulation of genes encoding metallothioneins, $H M O X 1$, and other components of the Nrf2 pathway, which protects against oxidative stress. DNA repair genes (XCP, GADD45G, RAD9, and $X R C C 1)$, protective genes (EGFR and $P P A R D)$, and genes of the NF $\mathcal{B} \mathrm{B}$ pathway were upregulated. Finally, tissue-cultures treated prophylactically with NAC-QYD showed significant downregulation of apoptosis, cytokines and chemokines genes, and constrained damage-associated molecular patterns (DAMPs). NAC-QYD treatment involves the protective effect of Nrf2, NF $\kappa \mathrm{B}$, and DNA repair factors.

\section{Introduction}

Mucositis is a debilitating disease that causes ulcers in the mouths or intestines of cancer patients who are treated with radiation or chemotherapy, resulting in pain and difficulty in eating and therefore contributing to their morbidity. In severe cases of mucositis, the therapeutic radiation regimen has to be modified or stopped, preventing the cancer patient from receiving the required therapy.

Mucositis develops over five phases [1]. The first is the initiation phase. Immediately after radiation or chemotherapy, reactive oxygen species form, which cause mucosal damage to the mouths or intestines of these patients. The initiation phase is considered to be a critical stage in the development of mucositis; by preventing this stage, mucositis-related injuries may be minimized. Thus, effective prevention of mucositis must happen at the initiation stage. The second is the signaling phase, which is characterized by message generation and the upregulation of cytokines and other factors. The third is the amplification phase, which is characterized by the increased production of cytokines that cause ulceration. The fourth is the bacterial colonization of ulcers. Mucositis 
clinically manifests at this stage. The fifth is the healing phase, during which the integrity of the mucosal layer is restored [24].

There are few prophylactic or therapeutic treatments for mucositis. Among the available treatments, $\mathrm{N}$-acetyl cysteine (NAC) has been evaluated in a randomized, double-blind placebo controlled study of 110 patients with head and neck cancer who received daily radiation therapy. At the highest cumulative radiation therapy dose, the incidence of severe oral mucositis (grade 3 or 4 ) was significantly lower among patients receiving NAC $[2,5,6]$. Another therapy, Qingre Liyan decoction (QYD), is a traditional Chinese medicine decocted from a mixture of twelve different plant products: Flos Lonicerae (Lonicera japonica) $15 \mathrm{~g}$, Belamcandae Rhizoma (Belamcanda chinensis) $15 \mathrm{~g}$, Lasiosphaera seu calvatia (Lasiosphaera fenzlii Reich, Calvatia gigantea) $9 \mathrm{~g}$, Astragali Radix (Astragalus membranaceus) 30 g, Glehniae Radix (Glehnia littoralis) $30 \mathrm{~g}$, Ophiopogonis Radix (Ophiopogon japonicus) $30 \mathrm{~g}$, Trichosanthes Radix (Trichosanthes kirilowii) $15 \mathrm{~g}$, Scrophulariae Radix (Scrophularia ningpoensis) $15 \mathrm{~g}$, Ligusticum wallichii Rhizoma (Ligusticum chuanxiong) $15 \mathrm{~g}$, Agrimoniae Herba (Agrimonia pilosa) 20 g, Imperatae Rhizoma (Imperata cylindrica) $9 \mathrm{~g}$, and Glycyrrhizae Radix (Glycyrrhiza uralensis) $10 \mathrm{~g}$. In a randomized trial, QYD significantly reduced the incidence of severe mucositis in patients receiving radiation therapy to the head and neck region, compared to the control group who were administered Dobell's solution [7].

Models of oral mucositis include monolayer cell cultures of human keratinocytes (2D), three-dimensional (3D) human cell tissue-culture of oral epithelia, biopsies, and in vitro reconstructed skin [8-11]. The 3D cell cultures are more realistic models compared to the $2 \mathrm{D}$ cell cultures because cells live in three dimensions. A 3D model of human oral epithelia has been established and the effect of different doses of radiation has been evaluated using histology and transcriptional studies [8].

In this study, we used a validated organotypic model of oral mucosal tissues consisting of a 3D cell tissue-culture of primary human keratinocytes, and we evaluated the prophylactic effects of NAC, QYD, and NAC-QYD by studying the tissue histology, apoptosis, and gene expression. We found that tissues treated with NAC-QYD preserved their integrity and showed no apoptosis. Microarrays showed that NACQYD-treated tissue had significantly upregulated metallothioneins, HMOX1, and other genes of the Nrf2 pathway, which protect cells against oxidative stress; DNA repair genes were also significantly upregulated, as well as EGFR, PPARD, and genes encoding the NF $\kappa$ B pathway. Furthermore, NACQYD-treated tissues showed significantly downregulated cytokines and chemokines as well as constrained DAMPs.

\section{Materials and Methods}

2.1. Three-Dimensional (3D) Tissues. This study utilized 3D human cell culture tissues (EpiOral MatTek Corporation, Ashland, MA), which have been validated as a human tissue substitute of oral mucosal. This is an organotypic model which consisted of primary human buccal keratinocytes grown in Millipore Millicell tissue-culture plate inserts using serum-free media at $37^{\circ} \mathrm{C}$ with $5 \% \mathrm{CO}_{2}$. The attained $3 \mathrm{D}$ cultures were highly differentiated and morphologically similar to human buccal epithelia with an organized basal layer and multiple apical noncornified layers. The 3D EpiOral tissue and media (containing specially prepared phenol red, $5 \mu \mathrm{g} / \mathrm{mL}$ gentamicin, and $0.25 \mu \mathrm{g} / \mathrm{mL}$ amphotericin B) were purchased from MatTek Corporation (Ashland, MA). For this experiment, the apical surface of the $3 \mathrm{D}$ tissues was exposed to $100 \mu \mathrm{L}$ of one of the following mixtures for $2 \mathrm{~h}$ at $37^{\circ} \mathrm{C}$ : (a) $1 \mathrm{mM}$ NAC, (b) $5 \mathrm{mg} / \mathrm{mL}$ QYD, or (c) an NAC-QYD mixture consisting of $1 \mathrm{mM}$ NAC and $4.5 \mathrm{mg} / \mathrm{mL}$ QYD. Then, the tissues were rinsed with phosphate-buffered saline (PBS) to remove the treatment materials and transferred to new plates with fresh culture medium. At least three independent $3 \mathrm{D}$ oral tissues were used for each treatment.

2.2. Irradiation. The $3 \mathrm{D}$ oral tissues were irradiated at the City of Hope (Duarte, CA) facility. The dose of the gamma irradiation exposure was $12 \mathrm{~Gy}$. After irradiation, the tissues were incubated for $6 \mathrm{~h}$ at $37^{\circ} \mathrm{C}$ with $5 \% \mathrm{CO}_{2}$. Subsequently, some of the tissues were used for the extraction of total RNA, and others were placed in 10\% formalin for histopathological studies.

2.3. TUNEL Assay. A TUNEL assay with the Cell Death Detection Kit (Roche, Philadelphia, PA) was used to visualize apoptotic cells. The 3D tissue was treated with proteinase $\mathrm{K}$ and rinsed twice. Then, a buffer containing a labeled nucleotide mix and TdT enzyme was added to the tissue, and the samples were incubated in a humidified chamber at $37^{\circ} \mathrm{C}$ for $1 \mathrm{~h}$. TUNEL staining was observed using a fluorescence microscope (Nikon Eclipse, Nikon Instruments, Inc., Melville, NY).

2.4. Traditional Chinese Medicine Qingre Liyan (QYD). The Traditional Chinese medicine, Qingre Liyan decoction, was provided by Dr. Moses S. S. Chow. It was prepared fresh from powder just before the experiments in serum-free media specially formulated by MatTek Corporation (Ashland, MA) (containing phenol red, $5 \mu \mathrm{g} / \mathrm{mL}$ gentamicin, and $0.25 \mu \mathrm{g} / \mathrm{mL}$ amphotericin B) and sonicated for 30 minutes. The mixture was centrifuged at $3,000 \mathrm{rpm}$ for four minutes and the supernatant was used to treat the $3 \mathrm{D}$ tissues.

2.5. Histology. The $3 \mathrm{D}$ tissue samples were placed in $10 \%$ formalin. The tissues were then stained with hematoxylin and eosin ( $\mathrm{H}$ and $\mathrm{E}$ ) and evaluated microscopically to assess the prophylactic effect of the treatments on the irradiation damage.

2.6. Gene Expression. The RNeasy Plus Mini Kit (Qiagen, Germantown, MD) was used to extract total RNA from the treated and untreated $3 \mathrm{D}$ tissues. A DNA microarray analysis was performed using the Human Whole Genome OneArray (Phalanx Biotech, Palo Alto, CA). The quality and integrity of the RNA were determined using an Agilent 2100 Bioanalyzer (Agilent Technologies, Palo Alto, CA) by monitoring the 


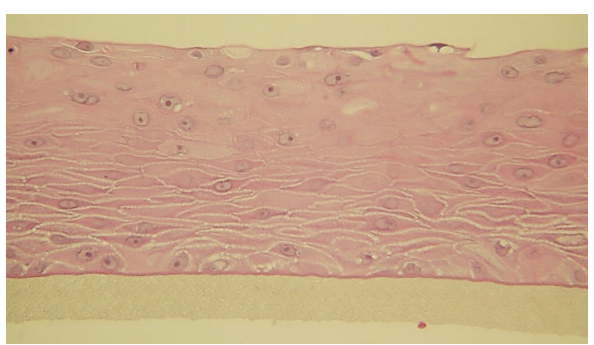

(a)

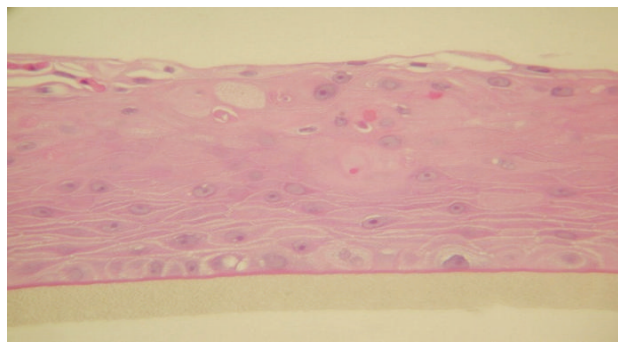

(c)

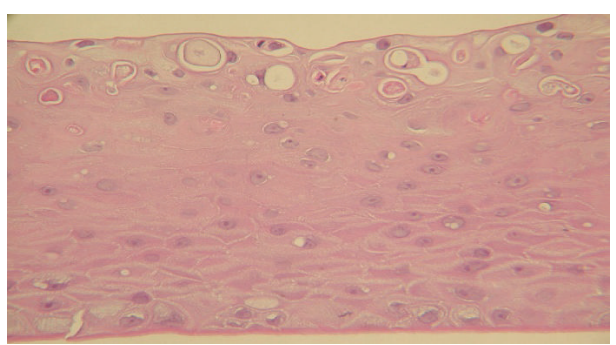

(b)

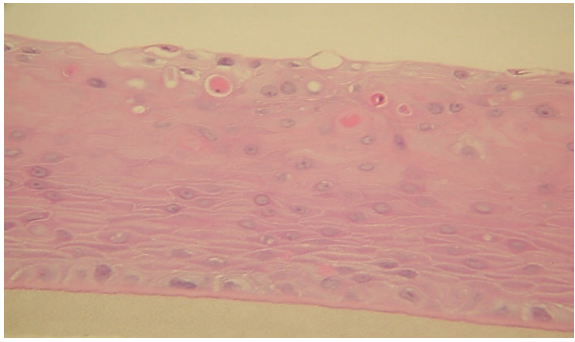

(d)

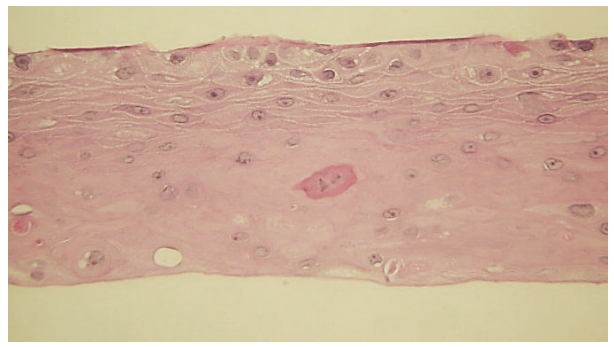

(e)

FIGURE 1: $\mathrm{H}$ and E staining of 3D-cultured human oral tissue. Nonirradiated, nontreated oral epithelium (negative control) consists of human oral keratinocytes and is divided into the stratum basalis (basal layer), stratum spinosum (the spindle shaped cell layer), and the stratum corneum (a); irradiated, nontreated tissue (positive control). Keratinocyte injury is noticeable at the top of the tissues, with an increased number of pyknotic cells at the bottom of the tissue (b); irradiated tissue prophylactically treated with NAC shows keratinocyte injury at the top of the tissue (c); irradiated tissue prophylactically treated with QYD shows keratinocyte injury (d); irradiated tissue prophylactically treated with NACQYD shows no injury and resembles the nonirradiated, nontreated negative control tissues (e).

A260/280 absorbance. Only RNA of the highest quality was used for analysis (RIN > 7.0 and A260/280 absorbance ratio > $1.8)$.

RNA was converted to double-stranded cDNA and amplified using an in vitro transcription reaction that included aminoallyl UTP. Then, the cDNA product was conjugated to Cy5 NHS ester (GE Healthcare Life Sciences, Pittsburg, PA). Fragmented RNA was hybridized overnight at $42^{\circ} \mathrm{C}$ using the HybBag mixing system with $1 \times$ OneArray Hybridization Buffer (Phalanx Biotech, San Diego, CA) and $0.01 \mathrm{mg} / \mathrm{mL}$ sheared salmon sperm DNA (Promega, Madison, WI). The labeled target concentration was $0.025 \mathrm{mg} / \mathrm{mL}$. After hybridization, the arrays were washed according to the OneArray protocol.

A Molecular Dynamics Axon 4100A scanner was used to capture the raw intensity signals produced by each of the microarrays. The signals were measured using GenePix Pro software and stored in GPR format. The Rosetta Resolver (Rosetta Biosoftware) was used to analyze the data from all microarrays in each experimental set. Testing was performed in triplicate by combining technical replicates and performing statistical analyses using the proprietary modeling techniques of the Rosetta Resolver. Then the data were imported into a Microsoft Excel database, with the corresponding gene names. The data were also deposited to Gene Expression Omnibus (GEO, accession number GSE62397).

\section{Results and Discussion}

3.1. Tissues Pretreated with NAC-QYD Are Not Affected by Radiation. Using a 3D human cell culture model of oral keratinocytes, we studied the protective effect of three treatments on radiation damage. $\mathrm{H}$ and $\mathrm{E}$ staining of the nonirradiated tissue revealed a healthy, well-differentiated multilayer epithelium consisting of keratinocytes. In the lower part of the epithelium, the stratum basalis and stratum spinosum layers, consisting of cylindrical cells and elongated spindle cells, respectively, could be distinguished (Figure 1(a)). Untreated tissue samples irradiated with 12 Gy showed laceration and damage to the top part of the tissues (Figure 1(b)) and the 


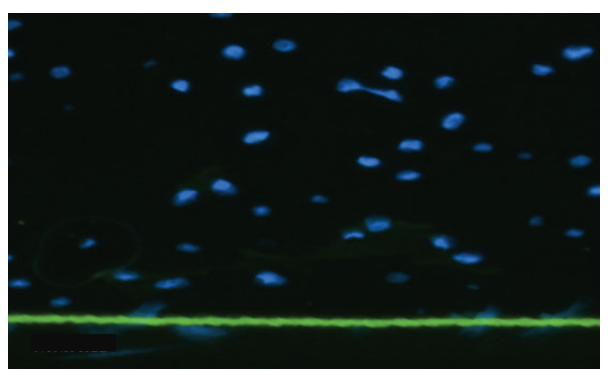

(a)

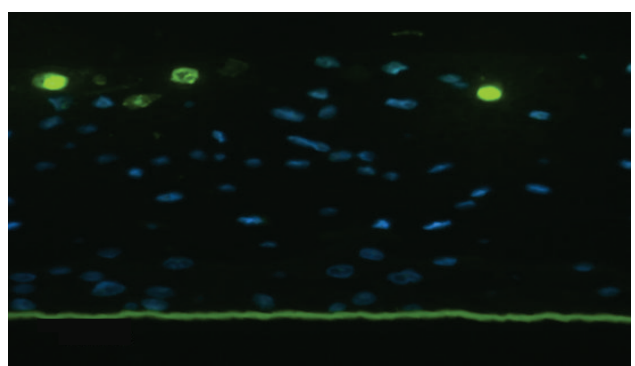

(c)

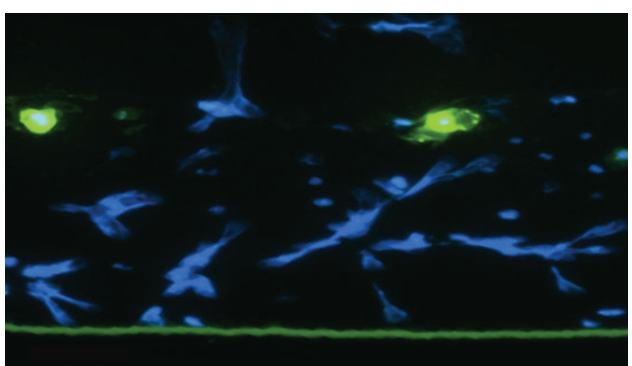

(b)

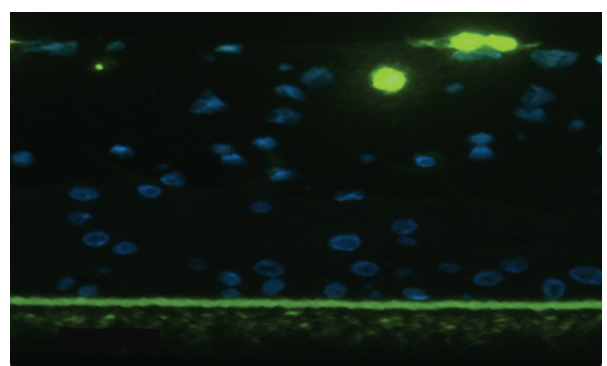

(d)

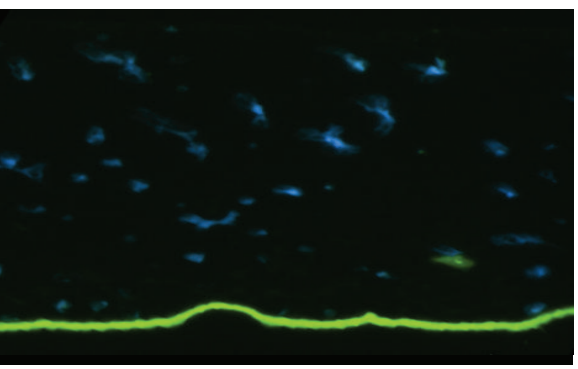

(e)

FiguRE 2: The apoptotic cells are stained in bright green. Nonirradiated, nontreated tissue (a); irradiated, nontreated tissue (b); irradiated tissue treated with NAC (c); irradiated tissue treated with QYD (d); irradiated tissue treated with NAC-QYD shows no apoptotic cells (e).

presence of apoptotic cells (Figure 2(b)). Tissues pretreated with NAC before irradiation also revealed the formation of edematous and apoptotic cells (Figures 1(c) and 2(c)). The pretreatment of tissues with QYD showed fewer edematous cells (Figure $1(\mathrm{~d})$ ) compared with those pretreated with NAC (Figure 1(c)); however, the pretreatment with NAC-QYD resulted in healthy $3 \mathrm{D}$ tissue (Figure $1(\mathrm{e})$ ) similar to the findings in the nonirradiated tissue.

The TUNEL assays revealed the absence of apoptotic cells in the nonirradiated (control) (Figure 2(a)) and NAC-QYD tissues (Figure 2(e)); in contrast, the irradiated, untreated tissues and the irradiated, NAC- and QYD-pretreated tissues showed the presence of apoptotic cells (Figures 2(b)-2(d)).

\subsection{NAC-QYD Treatment Affords Protection from Radiation} via Nrf2 and DNA Repair. In this experiment, the genes that encode components of the nuclear factor erythroid 2-related factor (Nrf2) pathway, such as HMOX1, MT1E, and MT2A, were significantly upregulated by the NAC-QYD treatment, whereas G6PD, NQO2, TXNRD1, and UGT1A10 were significantly upregulated by both the QYD and the NAC-QYD treatments (Table 1). Ionizing radiation causes cells to experience oxidative stress, which the cells must counteract to maintain homeostasis. Nrf2 is a transcription factor and a key controller of cell redox homeostasis [12]. Upregulated Nrf2 helps cells to counteract oxidative stress and survive $[13,14]$. Upregulation of Nrf2 protected skin cells treated with Feverfew extracts from UV oxidative damage and induced DNA repair [15].

In this study, genes encoding metallothioneins (MTs) were among those that were the most upregulated, more than 10 -fold in the case of the combination NAC-QYD treatment (Table 1). Metallothioneins reduce free radical species, regulate redox and apoptotic states, and have been shown to benefit cases of drug-induced toxicity and sepsis [16, 17]. MT1 and MT2 mRNA levels were also increased after the treatment of HEPG2 cells with sulforaphane [18].

There was also significant upregulation of the heme oxygenase-1 gene, HMOX1 (which is also known as HO-1) in the NAC-QYD prophylactically treated tissues (Table 1). The upregulation of $H M O X 1$ is a hallmark of Nrf2 activation [19]. HMOX1 is a cytoprotective enzyme which inhibits the reactive oxygen species (ROS) and induces anti-inflammatory 
TABLE 1: Genes pertaining to Nrf2 and NFאB pathways, cytokines, and inflammatory response that are upregulated or downregulated in NAC, QYD, or NAC-QYD pretreated human 3D-cultured oral tissues after 12 Gy irradiation.

\begin{tabular}{|c|c|c|c|c|c|c|}
\hline \multirow[t]{2}{*}{ Gene symbol } & \multicolumn{4}{|c|}{$\begin{array}{l}\text { Fold change compared with nonirradiated and untreated control } \\
\qquad\left({ }^{*} P<0.05\right)\end{array}$} & \multirow[t]{2}{*}{ Entrez gene } & \multirow[t]{2}{*}{ Gene description } \\
\hline & Untreated & NAC & TCM & NAC: TCM & & \\
\hline HMOX1 & 1.12 & 1.02 & 1.07 & $4.80^{*}$ & 3162 & Heme oxygenase (decycling) 1 \\
\hline MT1E & $0.76^{*}$ & $0.61^{*}$ & $0.36^{*}$ & $15.70^{*}$ & 4493 & Metallothionein 1E \\
\hline MT2A & 1.22 & 0.79 & $0.74^{*}$ & $10.41^{*}$ & 4502 & Metallothionein 2A \\
\hline$G 6 P D$ & 1.24 & 1.20 & $1.83^{*}$ & $2.81^{*}$ & 2539 & $\begin{array}{l}\text { Glucose-6-phosphate } \\
\text { dehydrogenase }\end{array}$ \\
\hline NQO2 & 1.15 & 1.32 & $1.35^{*}$ & $1.58^{*}$ & 4835 & $\begin{array}{l}\text { NAD }(\mathrm{P}) \mathrm{H} \text { Dehydrogenase, } \\
\text { quinone } 2\end{array}$ \\
\hline TXNRD1 & $0.43^{*}$ & 0.85 & $3.07^{*}$ & $3.14^{*}$ & 7296 & Thioredoxin reductase 1 \\
\hline UGT1A10 & 1.02 & 1.23 & $2.25^{*}$ & $1.59^{*}$ & 54659 & $\begin{array}{l}\text { UDP Glucuronosyltransferase } 1 \\
\text { family, polypeptide A10 }\end{array}$ \\
\hline MTIIP & 1.55 & $1.70^{*}$ & 1.11 & $12.99^{*}$ & 644314 & $\begin{array}{l}\text { Metallothionein 1IP } \\
\text { (pseudogene) }\end{array}$ \\
\hline MT1X & $1.82^{*}$ & $1.84^{*}$ & $1.51^{*}$ & $10.50^{*}$ & 4501 & Metallothionein 1X \\
\hline GADD45G & 1.13 & 1.07 & 1.01 & $1.53^{*}$ & 10912 & $\begin{array}{l}\text { Growth arrest and DNA damage } \\
\text { inducible gamma }\end{array}$ \\
\hline$R A D 9 A$ & 0.98 & 1.11 & 1.29 & $2.06^{*}$ & 5883 & RAD9 homolog A \\
\hline$X P C$ & 1.18 & $1.47^{*}$ & $1.57^{*}$ & $1.39^{*}$ & 7508 & $\begin{array}{l}\text { Xeroderma pigmentosum, } \\
\text { complementation group C }\end{array}$ \\
\hline$X R C C 1$ & 1.01 & $1.50^{*}$ & $1.46^{*}$ & $1.38^{*}$ & 7515 & $\begin{array}{l}\text { X-ray repair complementing } \\
\text { defective Repair in Chinese } \\
\text { hamster cells } 1\end{array}$ \\
\hline$J U N D$ & $1.81^{*}$ & $1.87^{*}$ & $2.43^{*}$ & $5.02^{*}$ & 3727 & Jun D protooncogene \\
\hline SIRT1 & $0.69^{*}$ & $0.76^{*}$ & 1.03 & 0.87 & 23411 & $\begin{array}{l}\text { Sirtuin (silent mating type } \\
\text { information regulation } 2 \\
\text { homolog) } 1 \text { (S. cerevisiae) }\end{array}$ \\
\hline PPARD & 0.86 & 0.83 & $0.50^{*}$ & $1.85^{*}$ & 5467 & $\begin{array}{c}\text { Peroxisome } \\
\text { proliferator-activated receptor } \\
\text { delta }\end{array}$ \\
\hline$R E L A$ & 1.27 & 1.04 & $1.54^{*}$ & $1.86^{*}$ & 5970 & $\begin{array}{l}\text { v-Rel reticuloendotheliosis viral } \\
\text { oncogene homolog A (avian) }\end{array}$ \\
\hline$R E L B$ & 1.136 & 1.04 & 1.26 & $2.30^{*}$ & 5971 & $\begin{array}{l}\text { v-Rel reticuloendotheliosis viral } \\
\text { oncogene homolog B }\end{array}$ \\
\hline NFKB2 & 1.10 & 1.10 & $1.50^{*}$ & $2.12^{*}$ & 4791 & $\begin{array}{l}\text { Nuclear factor of kappa light } \\
\text { polypeptide gene enhancer in } \\
\text { B-cells } 2(\mathrm{p} 49 / \mathrm{p} 100)\end{array}$ \\
\hline TNFA1P3 & $0.76^{*}$ & $0.68^{*}$ & 0.91 & $1.25^{*}$ & 7128 & $\begin{array}{l}\text { Tumor necrosis factor, } \\
\text { alpha-induced protein } 3\end{array}$ \\
\hline$N F K B I A$ & 0.83 & 0.96 & 1.01 & $1.25^{*}$ & 4792 & $\begin{array}{l}\text { Nuclear factor of kappa light } \\
\text { polypeptide gene enhancer in } \\
\text { B-cells inhibitor, alpha }\end{array}$ \\
\hline CXCL1 & $1.72^{*}$ & $0.54^{*}$ & $0.29^{*}$ & $0.27^{*}$ & 2919 & $\begin{array}{l}\text { Chemokine (C-X-C motif) } \\
\text { ligand } 1 \text { (melanoma growth } \\
\text { stimulating activity, alpha) }\end{array}$ \\
\hline CXCL2/CXCL3 & $2.13^{*}$ & 0.91 & $0.55^{*}$ & $0.54^{*}$ & $2920 \mid 2921$ & $\begin{array}{c}\text { Chemokine (C-X-C motif) } \\
\text { ligand } 2 / \text { chemokine }(\mathrm{C}-\mathrm{X}-\mathrm{C} \\
\text { motif) ligand } 3\end{array}$ \\
\hline CXCL6 & 1.22 & 1.04 & $0.65^{*}$ & $0.69^{*}$ & 6372 & $\begin{array}{c}\text { Chemokine (C-X-C motif) } \\
\text { ligand } 6 \text { (granulocyte } \\
\text { chemotactic protein } 2)\end{array}$ \\
\hline
\end{tabular}


TABLE 1: Continued.

\begin{tabular}{|c|c|c|c|c|c|c|}
\hline \multirow[t]{2}{*}{ Gene symbol } & \multicolumn{4}{|c|}{$\begin{array}{l}\text { Fold change compared with nonirradiated and untreated control } \\
\qquad\left({ }^{*} P<0.05\right)\end{array}$} & \multirow[t]{2}{*}{ Entrez gene } & \multirow[t]{2}{*}{ Gene description } \\
\hline & Untreated & NAC & TCM & NAC:TCM & & \\
\hline CXCL14 & 0.91 & 1.17 & $0.67^{*}$ & $0.51^{*}$ & 9547 & $\begin{array}{c}\text { Chemokine (C-X-C motif) } \\
\text { ligand } 14\end{array}$ \\
\hline CCL18 & 0.96 & 1.03 & 0.73 & $0.38^{*}$ & 6362 & $\begin{array}{c}\text { Chemokine (C-C motif) ligand } \\
18 \text { (pulmonary and } \\
\text { activation-regulated) }\end{array}$ \\
\hline CCL20 & 1.17 & $0.42^{*}$ & $0.42^{*}$ & $0.49^{*}$ & 6364 & $\begin{array}{l}\text { Chemokine (C-C motif) ligand } \\
20\end{array}$ \\
\hline$F A D D$ & 0.99 & $0.75^{*}$ & 0.97 & $0.70^{*}$ & 8772 & $\begin{array}{l}\text { Fas- (TNFRSF6-) associated via } \\
\text { the death domain }\end{array}$ \\
\hline CASP1 & 0.78 & $0.54^{*}$ & $0.44^{*}$ & $0.44^{*}$ & 834 & $\begin{array}{c}\text { Caspase 1, apoptosis-related } \\
\text { cysteine peptidase (interleukin-1, } \\
\text { beta, convertase) }\end{array}$ \\
\hline CASP8 & 0.81 & $0.53^{*}$ & $0.58^{*}$ & $0.59^{*}$ & 841 & $\begin{array}{l}\text { Caspase } 8 \text {, apoptosis-related } \\
\text { cysteine peptidase }\end{array}$ \\
\hline CASP10 & 0.97 & 1.08 & 1.03 & $0.70^{*}$ & 843 & $\begin{array}{l}\text { Caspase } 10 \text {, apoptosis-related } \\
\text { cysteine peptidase }\end{array}$ \\
\hline$S P 1$ & 1.15 & $1.51^{*}$ & $1.61^{*}$ & $1.82^{*}$ & 6667 & Sp1 transcription factor \\
\hline STAT3 & 0.92 & $1.31^{*}$ & 1.22 & $1.32^{*}$ & 6774 & $\begin{array}{c}\text { Signal transducer and activator } \\
\text { of transcription } 3 \text { (acute-phase } \\
\text { response factor) }\end{array}$ \\
\hline СЕВРВ & $1.5^{*}$ & 1.03 & 1.25 & $2.22^{*}$ & 1051 & $\begin{array}{l}\text { CCAAT/enhancer binding } \\
\text { protein, beta }\end{array}$ \\
\hline EGFR & $0.74^{*}$ & 0.95 & 1.07 & $1.48^{*}$ & 1956 & $\begin{array}{l}\text { Epidermal growth factor receptor } \\
\text { (erythroblastic leukemia viral } \\
\text { (v-erb-b) oncogene homolog, } \\
\text { avian) }\end{array}$ \\
\hline IL1B & 0.96 & 0.78 & $2.93^{*}$ & $1.25^{*}$ & 3553 & Interleukin-1, beta \\
\hline IL1R1 & 0.91 & 0.98 & $1.44^{*}$ & $1.54^{*}$ & 3554 & Interleukin-1 receptor, type I \\
\hline TNFS10 & 0.93 & 0.89 & $0.62^{*}$ & $0.46^{*}$ & 8743 & $\begin{array}{l}\text { Tumor necrosis factor (ligand) } \\
\text { superfamily, member } 10\end{array}$ \\
\hline IRZAK1BP1 & 1.01 & 0.86 & $0.68^{*}$ & $0.52^{*}$ & 134728 & $\begin{array}{l}\text { Interleukin-1 receptor-associated } \\
\text { kinase } 1 \text { binding protein } 1\end{array}$ \\
\hline$I R A K 2$ & 0.9 & 1.02 & 1.18 & $1.73^{*}$ & 3656 & $\begin{array}{c}\text { Interleukin-1 receptor-associated } \\
\text { kinase } 2\end{array}$ \\
\hline MYD88 & $0.65^{*}$ & 0.82 & $0.76^{*}$ & 1.10 & 4615 & $\begin{array}{l}\text { Myeloid differentiation primary } \\
\text { response gene (88) }\end{array}$ \\
\hline CHUK & $0.72^{*}$ & $0.74^{*}$ & 0.939 & 0.89 & 1147 & $\begin{array}{l}\text { Conserved helix-loop-helix } \\
\text { ubiquitous kinase }\end{array}$ \\
\hline NFKBIE & 0.96 & 0.85 & 0.88 & $1.59^{*}$ & 4794 & $\begin{array}{l}\text { Nuclear factor of kappa light } \\
\text { polypeptide gene enhancer in } \\
\text { B-cells inhibitor, epsilon }\end{array}$ \\
\hline NFKBIB & $0.77^{*}$ & $1.25^{*}$ & $1.33^{*}$ & 1.08 & 4793 & $\begin{array}{l}\text { Nuclear factor of kappa light } \\
\text { polypeptide gene enhancer in } \\
\text { B-cells inhibitor, beta }\end{array}$ \\
\hline BCL2L10 & 1.47 & 1.70 & 1.09 & 0.57 & 10017 & $\begin{array}{l}\text { BCL2-like } 10 \text { (apoptosis } \\
\text { facilitator) }\end{array}$ \\
\hline$J U N B$ & 1.10 & 0.87 & 1.26 & $1.65^{*}$ & 3726 & Jun B protooncogene \\
\hline CDKNIA & 1.16 & $1.61^{*}$ & $1.60^{*}$ & $2.42^{*}$ & 1026 & $\begin{array}{l}\text { Cyclin-dependent kinase 1A (p21, } \\
\text { Cip1) }\end{array}$ \\
\hline
\end{tabular}




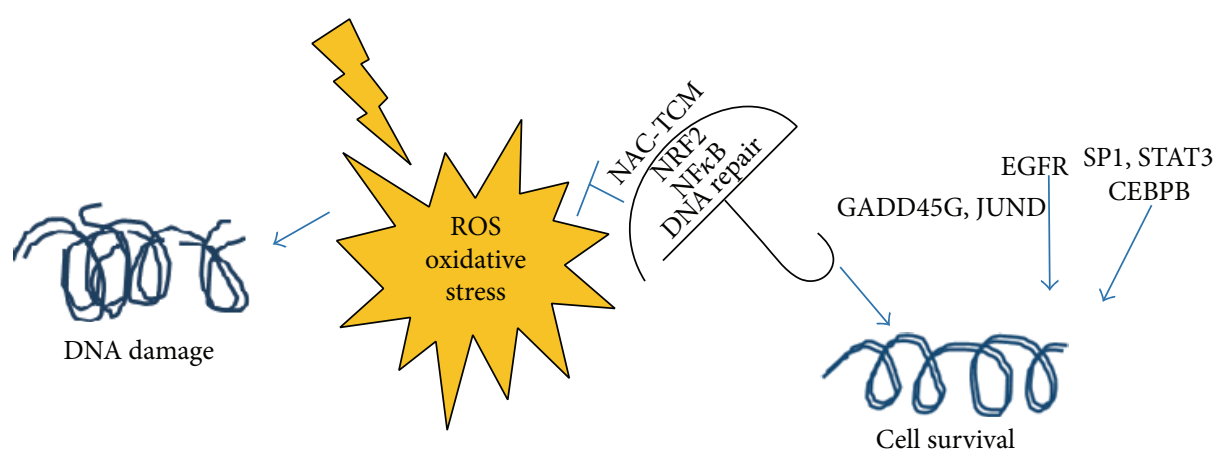

FIGURE 3: A schematic representation of the proposed molecular signatures which were elicited by the synergistic effect of NAC-QYD and prevented the radiation damage.

responses [20, 21]. Increased HMOX1 expression is observed in endothelial cells and is triggered by $\mathrm{TNFa}$ via the $\mathrm{NF} \kappa \mathrm{B}$ pathway [22]. Our data parallel this finding; the upregulation of HMOX1 was accompanied by the increased expression of several genes that belong to the $\mathrm{NF} \kappa \mathrm{B}$ pathway, as discussed later.

Another gene that encodes an antioxidant protein, NQO2, was upregulated by the QYD and NAC-QYD treatments (Table 1). NQO2 is a flavoprotein that catalyzes the metabolic reductive detoxification of redox cycling quinones [23]. Moreover, the glucose-6-phosphate dehydrogenase (G6PDH) and thioredoxin reductase 1 (TXNRD1) were significantly upregulated in the QYD- and NAC-QYD-treated tissues (Table 1). Both genes are transcriptionally regulated by Nrf2. G6PDH is of crucial importance to cells for protection from oxidative damage and is involved in the generation of NADPH which preserves the redox potential of the cell. TXNRD1 is also important for detoxification and maintaining the cellular redox potential so that the cell can respond appropriately to stresses such as inflammation [24, 25].

Tissues that received the combination NAC-QYD treatment demonstrated an upregulation of DNA repair genes such as GADD45G, RAD9, XPC, and XRCCI (Table 1). The GADD45G protein plays a protective role in cells and enhances cell survival by inducing DNA repair and arresting the cell cycle [26]. In our study, JUND was significantly upregulated ( 5 -fold) by the combination treatment (Table 1 ). The deletion of JUND is known to induce oxidative stress; the corresponding protein has been shown to provide protection in age-related endothelial dysfunction [27].

3.3. NFאB Activation in NAC-QYD-Pretreated Tissues. Several genes that belong to the $\mathrm{NF} \kappa \mathrm{B}$ pathway were differentially expressed between the control and the combination NACQYD-treated or single agent-treated tissues. RELA, RELB, $R E L$, and NFKB2 were significantly upregulated in the NACQYD-treated tissues (Table 1 ). NF $\kappa$ B regulates many diverse cell functions related to immune, inflammatory, and apoptotic responses. $\mathrm{NF} \kappa \mathrm{B}$ levels are affected by irradiation and are involved in the prevention of apoptosis, facilitate DNA repair, and contribute to cell radio-resistance [28-31].

The activation of $\mathrm{NF} \kappa \mathrm{B}$ leads to the induction of inflammatory cytokines; however, $\mathrm{NF} \kappa \mathrm{B}$ also induces genes, such as TNFAIP3 (A20), which reduce the extent and duration of the inflammatory response, thereby preventing inflammation from causing further tissue damage [32]. In our study, TNFAIP3 was upregulated in the NAC-QYD tissue but downregulated in the NAC-treated and nontreated irradiated tissues, which may explain the observation that genes encoding some cytokines and chemokines, such as CXL1, CXL6, CXL14, CXL16, CCL18, and CCL20, were downregulated in the tissues treated with NAC-QYD (Table 1). TNFAIP3 also perturbs caspase activation of TNF receptor 1 (TNFR1) which is coupled to apoptotic caspases 8 and $10[28,33]$.

In our study, FADD, CASP1, CASP8, and CASP10 were significantly downregulated in NAC-QYD tissue. This finding also supports the TUNEL studies, which show no apoptosis in the NAC-QYD-treated tissues. Other genes that act in synergy with $\mathrm{NF} \kappa \mathrm{B}$ are $S P 1, S T A T 3$, and $C E B P B$, which were found to be upregulated in the tissues that received the NACQYD treatment. Cross talk among NF $\kappa$ B, SP1, and STAT3 is important for wound healing, whereas silencing the corresponding genes has been shown to impair wound healing in keratinocytes [34].

Our study showed that the combination treatment may have enhanced the radio-protective role of $\mathrm{NF} \kappa \mathrm{B}$ and concurrently controlled the $\mathrm{NF} \kappa \mathrm{B}$-mediated inflammation via the upregulation of TNFAIP3. The radio-protective role of $\mathrm{NF} \kappa \mathrm{B}$ has previously been demonstrated in the case of irradiated intestinal epithelial cells $[35,36]$.

EGFR was upregulated significantly in the NAC-QYDtreated tissues and downregulated in the nontreated irradiated tissues. Signaling through EGFR has been shown to induce $\mathrm{NF} \kappa \mathrm{B}$ activation and enhance cell survival, whereas blocking EGFR signaling results in the inhibition of $\mathrm{NF} \kappa \mathrm{B}$ $[37,38]$. A schematic representation of the protective molecular signatures discussed above is shown in Figure 3.

3.4. Constrained DAMPs in Tissues Pretreated with NACQYD. Pathogens and trauma cause damage to tissues and cells. Cells respond to this damage by releasing molecules that announce the injury to the surrounding tissues. Molecular patterns of endogenous molecules that signal tissue injury are called DAMPs. DAMPs are released by stressed cells that undergo necrosis and promote inflammatory responses. Common DAMPs include the expression of the toll-like 
TABLE 2: Genes related to damage-associated molecular patterns (DAMPs) that are upregulated or downregulated in NAC, TCM or NACTCM pretreated human 3D-cultured oral tissues after 12 Gy irradiation.

\begin{tabular}{|c|c|c|c|c|c|c|}
\hline \multirow[t]{2}{*}{ Gene symbol } & \multicolumn{4}{|c|}{$\begin{array}{l}\text { Fold change compared with nonirradiated and untreated control } \\
\qquad\left({ }^{*} P<0.05\right)\end{array}$} & \multirow[t]{2}{*}{ Entrez gene } & \multirow[t]{2}{*}{ Gene description } \\
\hline & Untreated & NAC & TCM & NAC-TCM & & \\
\hline S100A16 & 0.94 & 0.98 & 0.88 & $0.76^{*}$ & 140576 & $\begin{array}{l}\text { S100 calcium-binding } \\
\text { protein A16 }\end{array}$ \\
\hline S100A12 & $1.47^{*}$ & 1.05 & 1.24 & 1.20 & 6283 & $\begin{array}{l}\text { S100 calcium-binding } \\
\text { protein A12 }\end{array}$ \\
\hline S100A11 & $1.29^{*}$ & 1.03 & 1.20 & 1.09 & 6282 & $\begin{array}{l}\text { S100 calcium-binding } \\
\text { protein A11 }\end{array}$ \\
\hline$R A G E(A G E R)$ & 1.10 & 1.18 & $0.77^{*}$ & $0.57^{*}$ & 177 & $\begin{array}{l}\text { Receptor of advanced } \\
\text { glycosylation end-products }\end{array}$ \\
\hline$S A A 1$ & $1.32^{*}$ & $1.59^{*}$ & 0.89 & 0.87 & 6288 & Serum amyloid A1 \\
\hline$S A A 2$ & $1.20^{*}$ & $1.23^{*}$ & 1.08 & 1.00 & 6289 & Serum amyloid A2 \\
\hline$T L R 2$ & 1.10 & 1.07 & 0.79 & 0.70 & 7097 & Toll-like receptor 2 \\
\hline $\operatorname{IL} 1 R 2$ & $0.36^{*}$ & $0.56^{*}$ & $0.53^{*}$ & $0.52^{*}$ & 7850 & $\begin{array}{l}\text { Interleukin-1 receptor, type } \\
\text { II }\end{array}$ \\
\hline IL1A & $0.71^{*}$ & 0.78 & $1.69^{*}$ & 0.98 & 3552 & Interleukin-1A \\
\hline
\end{tabular}

${ }^{*} P<0.05$.

receptors (TLRs), calcium-binding protein (S100A), the receptor of advanced glycosylation end-products such as $R A G E$ (which is also known as AGER), and serum amyloid protein $(S A A)$.

In this study, S100A16 and RAGE were downregulated by the NAC-QYD treatment, whereas S100A12, S100A11, SAA1, and SAA2 were upregulated in the irradiated, nontreated control (Table 2). The upregulation of the $S 100$ genes after irradiation is in agreement with results from our own and others' previous studies $[8,39]$. S100 proteins are markers of inflammation [40]. RAGE, which was significantly downregulated in the QYD and NAC-QYD treatments, encodes a multiligand receptor that can initiate and perpetuate inflammatory responses and interacts with S100 proteins [41]. SAAs are considered to be markers for inflammatory disease and are potent stimulators of G-CSF, which is important in the regulation of granulocytosis. The effect of SAAs depends on TLR2. In our experiment, TLR2 was downregulated in the NAC-QYD combination-treated tissue. Blocking TLR2 has been shown to ablate the ability of SAAs to stimulate G-CSF [42].

In summary, tissues treated prophylactically with the NAC-QYD combination remained primarily unaffected by the irradiation and, in terms of histology and apoptosis, resembled the nonirradiated tissue. These findings are in contrast with the tissues treated with NAC or QYD alone which showed some irradiation damage. This prophylactic effect is due to the enhanced activity of the Nrf2 and NF $\kappa$ B pathways, upregulation of DNA repair genes, reduced expression of chemokines and cytokines such as CXL1, CXL2/CXL3, CXL6, CXL14, CCL18, and CCL20, and constrained expression of DAMPs such as RAGE, S100, and SAA.

\section{Abbreviations}

QYD: Qingre Liyan decoction

TCM: Traditional Chinese medicine
Nrf2: $\quad$ Nuclear factor erythroid 2-related factor

DAMPs: Damage-associated molecular patterns

TLRs: Toll-like receptors

G6PDH: Glucose-6-phosphate dehydrogenase

HMOX1: Heme oxygenase-1

MT: $\quad$ Metallothionein.

\section{Conflict of Interests}

The authors declare that there is no conflict of interests regarding the publication of this paper.

\section{Acknowledgment}

The authors thank ARDF for their generous support of this research.

\section{References}

[1] S. T. Sonis, "New thoughts on the initiation of mucositis," Oral Diseases, vol. 16, no. 7, pp. 597-600, 2010.

[2] S. T. Sonis, "Pathobiology of oral mucositis: novel insights and opportunities," Journal of Supportive Oncology, vol. 5, no. 9, supplement 4, pp. 3-11, 2007.

[3] S. T. Sonis, "Mucositis: the impact, biology and therapeutic opportunities of oral mucositis," Oral Oncology, vol. 45, no. 12, pp. 1015-1020, 2009.

[4] D. M. Keefe, S. T. Sonis, and J. M. Bowen, "Emerging drugs for chemotherapy-induced mucositis," Expert Opinion on Emerging Drugs, vol. 13, no. 3, pp. 511-522, 2008.

[5] M. S. Chambers, "RK-0202 for radiation-induced oral mucositis," Journal of Clinical Oncology, vol. 24, no. 18, supplement, abstract 5523, 2006.

[6] D. I. Rosenthal and A. Trotti, "Strategies for managing radiation-induced mucositis in head and neck cancer," Seminars in Radiation Oncology, vol. 19, no. 1, pp. 29-34, 2009. 
[7] M.-H. Wu, B. Yuan, Q.-F. Liu, and Q. Wang, "Study of Qingre Liyan Decoction in treating and preventing acute radioactive oral mucositis," Chinese Journal of Integrative Medicine, vol. 13, no. 4, pp. 280-284, 2007.

[8] M. P. Lambros, C. Parsa, H. Mulamalla et al., "Identifying cell and molecular stress after radiation in a three-dimensional (3-D) model of oral mucositis," Biochemical and Biophysical Research Communications, vol. 405, no. 1, pp. 102-106, 2011.

[9] H. A. Rakhorst, S. J. Posthumus-Van Sluijs, W. M. W. Tra et al., "Fibroblasts accelerate culturing of mucosal substitutes," Tissue Engineering, vol. 12, no. 8, pp. 2321-2331, 2006.

[10] H. A. Rakhorst, W. M. W. Tra, S. J. Posthumus-van Sluijs et al., "Mucosal keratinocyte isolation: a short comparative study on thermolysin and dispase," International Journal of Oral and Maxillofacial Surgery, vol. 35, no. 10, pp. 935-940, 2006.

[11] H. A. Rakhorst, W. M. W. Tra, S. T. Posthumus-van Sluijs et al., "Quantitative analysis of radiation-induced DNA break repair in a cultured oral mucosal model," Tissue Engineering, vol. 12, no. 12, pp. 3395-3403, 2006.

[12] E. Warabi, W. Takabe, T. Minami et al., "Shear stress stabilizes NF-E2-related factor 2 and induces antioxidant genes in endothelial cells: Role of reactive oxygen/nitrogen species," Free Radical Biology and Medicine, vol. 42, no. 2, pp. 260-269, 2007.

[13] E. Kansanen, S. M. Kuosmanen, H. Leinonen, and A.-L. Levonenn, "The Keap1-Nrf2 pathway: mechanisms of activation and dysregulation in cancer," Redox Biology, vol. 1, no. 1, pp. 45-49, 2013.

[14] Y. Huang, W. Li, and A.-N. T. Kong, "Anti-oxidative stress regulator NF-E2-related factor 2 mediates the adaptive induction of antioxidant and detoxifying enzymes by lipid peroxidation metabolite 4-hydroxynonenal," Cell \& Bioscience, vol. 2, no. 1, article 40, 2012.

[15] K. J. Rodriguez, H.-K. Wong, T. Oddos, M. Southall, B. Frei, and S. Kaur, "A purified Feverfew extract protects from oxidative damage by inducing DNA repair in skin cells via a PI3-kinasedependent Nrf2/ARE pathway," Journal of Dermatological Science, vol. 72, no. 3, pp. 304-310, 2013.

[16] S. C. Wesselkamper, S. A. McDowell, M. Medvedovic et al., "The role of metallothionein in the pathogenesis of acute lung injury," American Journal of Respiratory Cell and Molecular Biology, vol. 34, no. 1, pp. 73-82, 2006.

[17] N. Hu, X. Han, E. K. Lane, F. Gao, Y. Zhang, and J. Ren, "Cardiac-specific overexpression of metallothionein rescues against cigarette smoking exposure-induced myocardial contractile and mitochondrial damage," PLoS ONE, vol. 8, no. 2, Article ID e57151, 2013.

[18] C.-T. Yeh and G.-C. Yen, "Effect of sulforaphane on metallothionein expression and induction of apoptosis in human hepatoma HepG2 cells," Carcinogenesis, vol. 26, no. 12, pp. 2138$2148,2005$.

[19] B. M. Hybertson, B. Gao, S. K. Bose, and J. M. McCord, "Oxidative stress in health and disease: the therapeutic potential of Nrf2 activation," Molecular Aspects of Medicine, vol. 32, no. 46, pp. 234-246, 2011.

[20] C. A. Piantadosi, C. M. Withers, R. R. Bartz et al., "Heme oxygenase-1 couples activation of mitochondrial biogenesis to anti-inflammatory cytokine expression," The Journal of Biological Chemistry, vol. 286, no. 18, pp. 16374-16385, 2011.

[21] S. Bolisetty, A. M. Traylor, J. Kim et al., "Heme oxygenase-1 inhibits renal tubular macroautophagy in acute kidney injury," Journal of the American Society of Nephrology, vol. 21, no. 10, pp. 1702-1712, 2010.
[22] K. H. Pulkkinen, S. Ylä-Herttuala, and A.-L. Levonen, "Heme oxygenase 1 is induced by miR-155 via reduced BACH1 translation in endothelial cells," Free Radical Biology \& Medicine, vol. 51, no. 11, pp. 2124-2131, 2011.

[23] A. K. Jaiswal, "Nrf2 signaling in coordinated activation of antioxidant gene expression," Free Radical Biology and Medicine, vol. 36, no. 10, pp. 1199-1207, 2004.

[24] H.-S. Zhang and S.-Q. Wang, "Nrf2 is involved in the effect of tanshinone IIA on intracellular redox status in human aortic smooth muscle cells," Biochemical Pharmacology, vol. 73, no. 9, pp. 1358-1366, 2007.

[25] J. M. Lee, M. J. Calkins, K. Chan, Y. W. Kan, and J. A. Johnson, "Identification of the NF-E2-related factor-2-dependent genes conferring protection against oxidative stress in primary cortical astrocytes using oligonucleotide microarray analysis," The Journal of Biological Chemistry, vol. 278, no. 14, pp. 12029-12038, 2003.

[26] D. Sarkar, X.-Y. Wang, and P. B. Fisher, "Targeting JunD: a potential strategy to counteract hormone-refractory prostate cancer," Cell Cycle, vol. 10, no. 20, p. 3433, 2011.

[27] F. Paneni, E. Osto, S. Costantino et al., "Deletion of the activated protein-1 transcription factor JunD induces oxidative stress and accelerates age-related endothelial dysfunction," Circulation, vol. 127, no. 11, pp. 1229-1240, 2013.

[28] N. Magne, R.-A. Toillon, V. Bottero et al., "NF- $\kappa$ B modulation and ionizing radiation: mechanisms and future directions for cancer treatment," Cancer Letters, vol. 231, no. 2, pp. 158-168, 2006.

[29] X. Chen, B. Shen, L. Xia et al., "Activation of nuclear factor $\kappa$ B in radioresistance of TP53-inactive human keratinocytes," Cancer Research, vol. 62, no. 4, pp. 1213-1221, 2002.

[30] A. K. Holley, Y. Xu, D. K. S. Clair, and W. H. S. Clair, "RelB regulates manganese superoxide dismutase gene and resistance to ionizing radiation of prostate cancer cells," Annals of the New York Academy of Sciences, vol. 1201, pp. 129-136, 2010.

[31] Y. Sun, D. K. St. Clair, F. Fang et al., "The radiosensitization effect of parthenolide in prostate cancer cells is mediated by nuclear factor- $\kappa \mathrm{B}$ inhibition and enhanced by the presence of PTEN," Molecular Cancer Therapeutics, vol. 6, no. 9, pp. 24772486, 2007.

[32] L. Vereecke, R. Beyaert, and G. van Loo, "The ubiquitin-editing enzyme A20 (TNFAIP3) is a central regulator of immunopathology," Trends in Immunology, vol. 30, no. 8, pp. 383-391, 2009.

[33] G. Chen and D. V. Goeddel, “TNF-R1 signaling: a beautiful pathway," Science, vol. 296, no. 5573, pp. 1634-1635, 2002.

[34] R. Melchionna, G. Bellavia, M. Romani et al., " $\mathrm{C} / \mathrm{EBP} \gamma$ regulates wound repair and EGF receptor signaling," Journal of Investigative Dermatology, vol. 132, no. 7, pp. 1908-1917, 2012.

[35] P. Dent, A. Yacoub, J. Contessa et al., "Stress and radiationinduced activation of multiple intracellular signaling pathways," Radiation Research, vol. 159, no. 3, pp. 283-300, 2003.

[36] J. S. Murley, Y. Kataoka, D. Cao, J. J. Li, L. W. Oberleyd, and D. J. Grdina, "Delayed radioprotection by NF $\kappa$ B-mediated induction of Sod2 (MnSOD) in SA-NH tumor cells after exposure to clinically used thiol-containing drugs," Radiation Research, vol. 162, no. 5, pp. 536-546, 2004.

[37] J. An and M. B. Rettig, "Epidermal growth factor receptor inhibition sensitizes renal cell carcinoma cells to the cytotoxic effects of bortezomib," Molecular Cancer Therapeutics, vol. 6, no. 1, pp. 61-69, 2007. 
[38] M. Jost, F. P. Gasparro, P. J. Jensen, and U. Rodeck, "Keratinocyte apoptosis induced by ultraviolet B radiation and CD95 ligation-differential protection through epidermal growth factor receptor activation and $\mathrm{Bcl}-\mathrm{x}_{L}$ expression," Journal of Investigative Dermatology, vol. 116, no. 6, pp. 860-866, 2001.

[39] E. L. Travis, G. Rachakonda, X. Zhou et al., "NRF2 deficiency reduces life span of mice administered thoracic irradiation," Free Radical Biology \& Medicine, vol. 51, no. 6, pp. 1175-1183, 2011.

[40] A. M. Piccinini and K. S. Midwood, "DAMPening inflammation by modulating TLR signalling," Mediators of Inflammation, vol. 2010, Article ID 672395, 21 pages, 2010.

[41] A. Saleh, D. R. Smith, L. Tessler et al., "Receptor for advanced glycation end-products (RAGE) activates divergent signaling pathways to augment neurite outgrowth of adult sensory neurons," Experimental Neurology, vol. 249, pp. 149-159, 2013.

[42] R. L. He, J. Zhou, C. Z. Hanson, J. Chen, N. Cheng, and R. D. Ye, "Serum amyloid A induces G-CSF expression and neutrophilia via Toll-like receptor 2,” Blood, vol. 113, no. 2, pp. 429-437, 2009. 


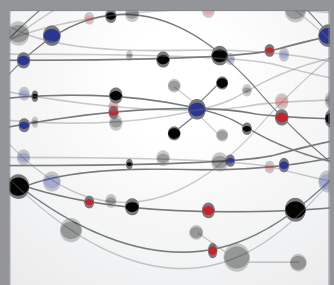

The Scientific World Journal
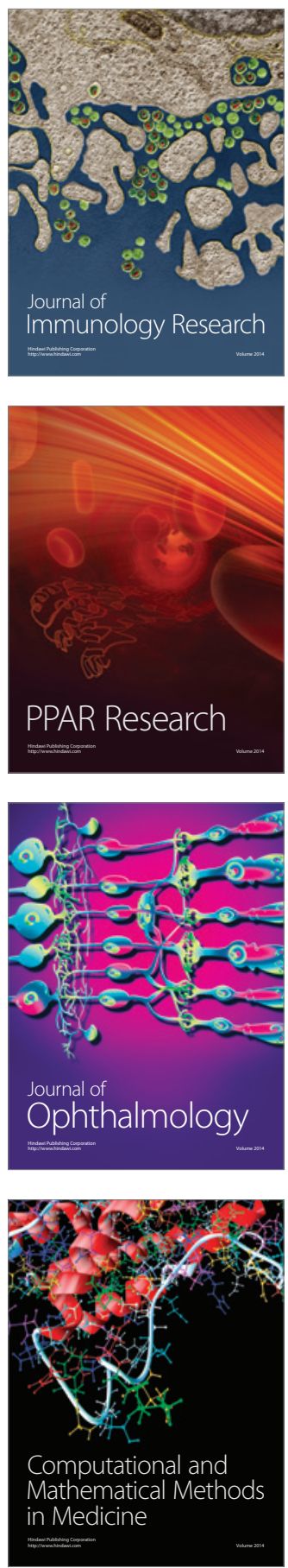

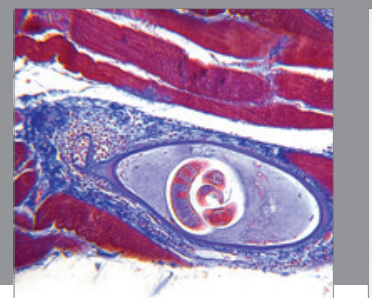

Gastroenterology

Research and Practice
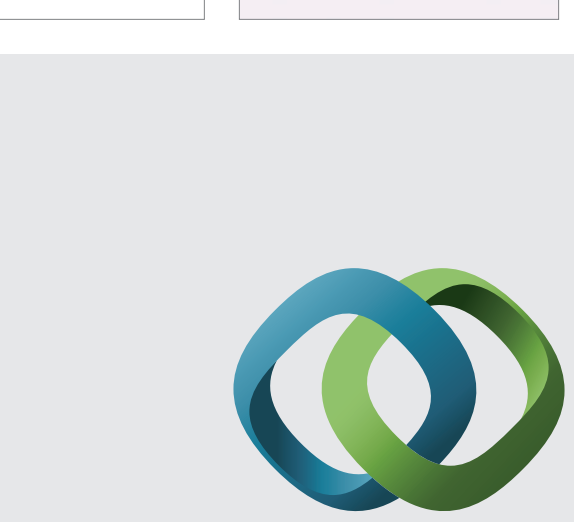

\section{Hindawi}

Submit your manuscripts at

http://www.hindawi.com
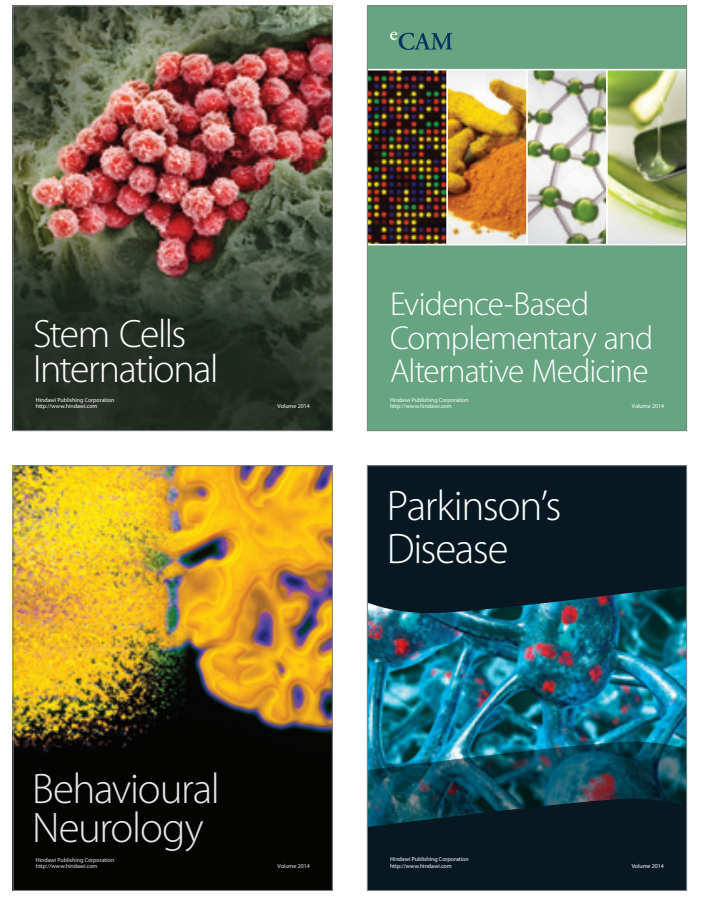
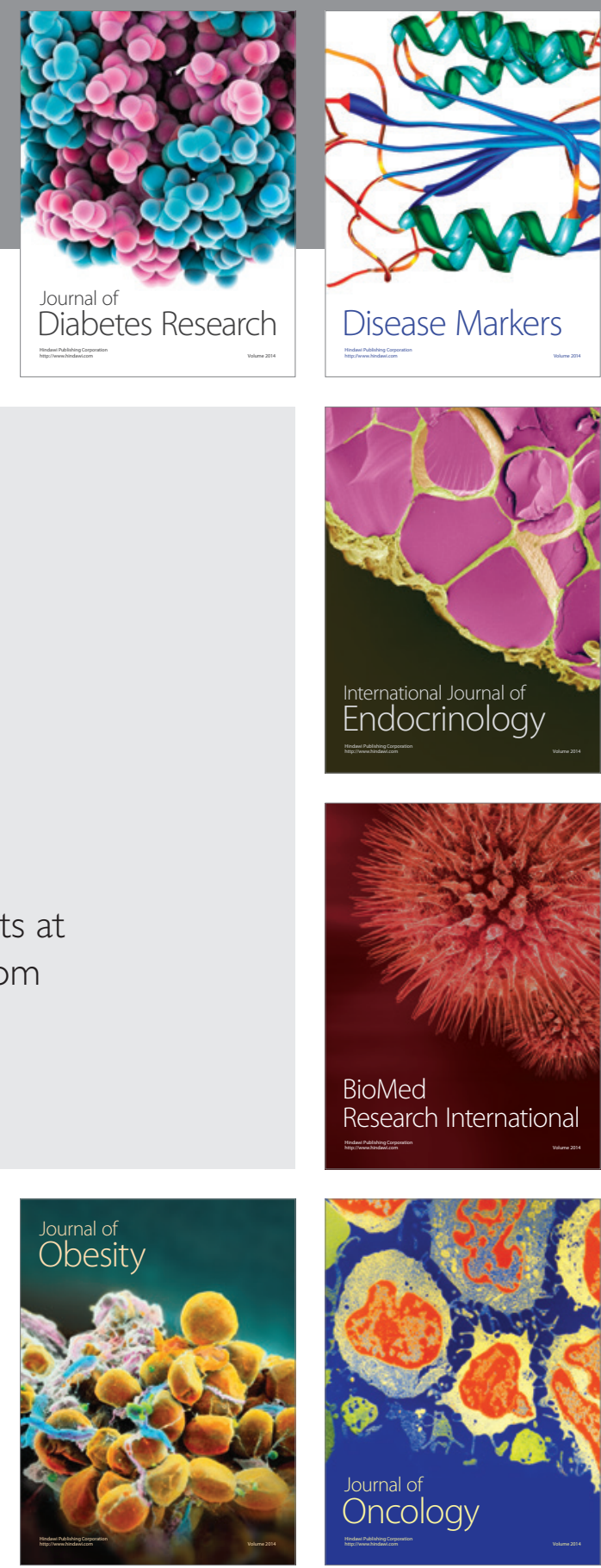

Disease Markers
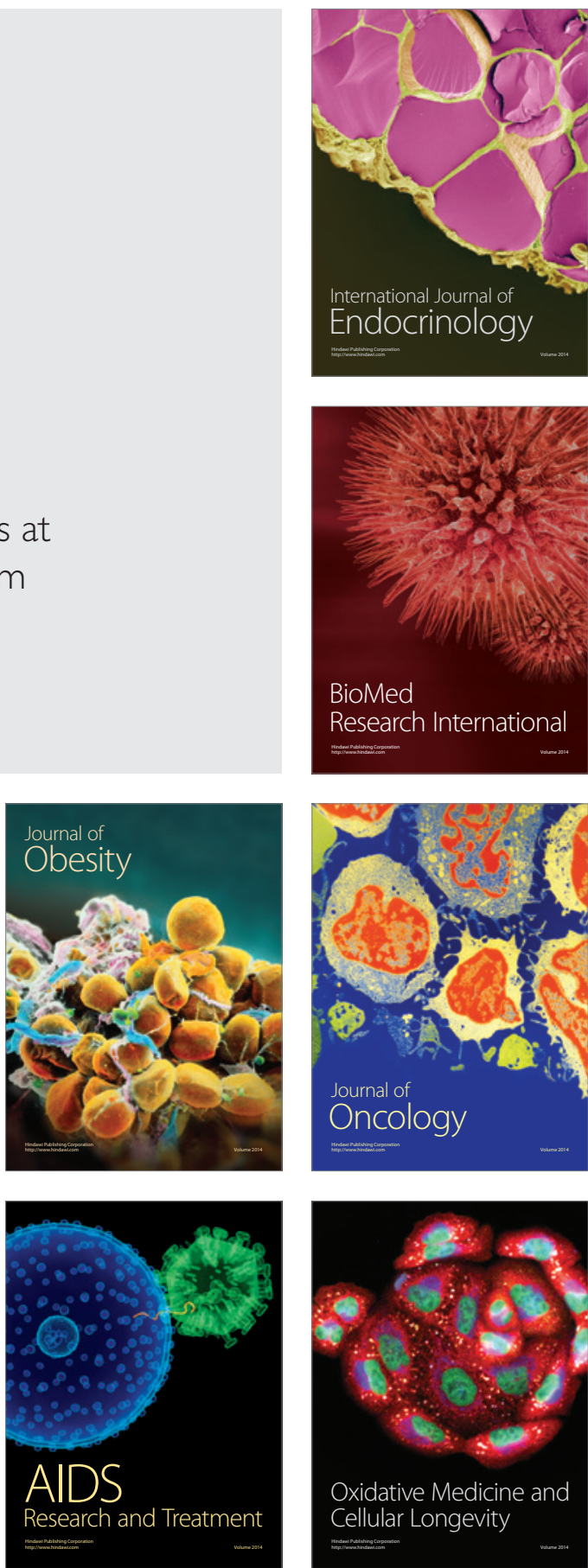